\title{
A KOGNITÍV KÉSZSÉGEK HATÁSA A DIPLOMÁS BÉREKRE
}

\author{
SEBŐK ANNA ${ }^{a, b}$

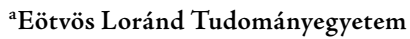 \\ ${ }^{\mathrm{b}}$ KRTK KTI \\ Beérkezett: 2020. december 13., elfogadva: 2021. június 13.
}

\begin{abstract}
Ebben a cikkben Magyarországon elsőként vizsgálom a kognitív készségek szerepét a felsőoktatási végzettség megtérülésében. Az adatok a KRTK Adatbank Kapcsolt Államigazgatási Paneladatbázisából származnak (Sebők 2019). Az adatforrás lehetővé teszi a különböző államigazgatási adatbázisok együttes vizsgálatát a magyar lakosság 50\%-os mintáján. Az elemzésben a 2008-ban 10. osztályos középiskolások kompetenciaeredményeit mint a korai kognitív készségek proxy változóját használom a hosszú távú diplomás pályakövetéses vizsgálatomban. A tanulmányban az oktatás hozamszámítási megközelítései közül a kereseti függvények módszerét alkalmazom.
\end{abstract}

Kulcsszavak: kompetencia, megtérülés, diplomás pályakövetés, kognitív készségek

This paper investigates the role of cognitive skills in the return to higher education (HE) in Hungary. It makes use of linked Hungarian administrative data, which contains labor market and educational information of about 50 percent of the Hungarian population, for the period of 2003 and 2017 (Sebök 2019). The estimates are focused on the early carrier path of HE graduates who completed their National Assessment of Basic Competencies 10th class tests in 2008. The paper uses Mincer-type regression models with the test scores as the the proxy variables of cognitive skills.

Keywords $¥$ competences, HE return, tracking, cognitive skills

\section{Bevezetés}

A tanulmányban azt vizsgálom, hogy a fiatalkori kognitív készségek hogyan hatnak a korai munkaerőpiaci sikerességre. A készségszint proxy változójaként a 10. osztályos kompetenciaeredményeket használom. A tanulmányban bemutatom, hogy átlagosan milyen általános készségekkel rendelkeztek középiskolás korukban

Levelező szerző: Sebők Anna, KRTK KTI, 1097 Budapest, Tóth Kálmán utca 4.

E-mail: sebok.anna@krtk.mta.hu 
a később érettségit, alap- vagy mesterképzést szerzett fiatalok. Ezek után arra keresem a választ, hogy a felsőoktatási végzettségek szerint, a különböző képzési területeken végzettek milyen átlagos kompetencia-pontszámmal rendelkeztek 10. osztályban. Ezt követően az összes végzettségtípus esetén megvizsgálom, hogy a korai kognitív készségek hogyan befolyásolják az azonos végzettségen belül elérthető fiatal felnőttkori béreket. Az elemzés során az is kiderül, hogy a különböző iskolai végzettségek menynyire térülnek meg, ha figyelembe vesszük az egyének készségszintjét. A tanulmányban arra is kitérek, hogy a béreloszlás különböző pontjain mennyire hat a diplomások készségszintje az elérhető bérekre.

A vizsgálatok koncepcionális hátterét a humántőke-elmélet adja. Az elmélet szerint az iskolai végzettség megszerzésével növekszik az egyéni termelékenység, ami az egyén szemszögéből magasabb bérekben és előnyösebb munkaerőpiaci helyzetben jelenik meg. Ebben a keretrendszerben a bérekre ható körülmények iskolai végzettségenkénti és szintenkénti vizsgálatával megállapítható, hogy mennyi az iskolai végzettség szintjéből adódó hozam és mennyit alakítanak a kereseteken az egyéb tényezők. A kompetenciaeredmények későbbi munkaerőpiaci sikerességben való megtérülését mincer-i keresetregressziókon keresztül ismertetem.

Hasonló vizsgálatra eddig nem volt példa, hiszen hazai államigazgatási regiszterek adatai eddig nem lettek összevonva más forrásból származó kvázi-teljeskörű adatfelvétellel. A vizsgálatban így először elemezhetők együtt a magyar népesség 50 százalékos mintáján a középiskolás kompetenciaeredmények (Országos kompetenciamérési adatok), a keresetek, a munkaerőpiaci életút (Nemzeti Adó- és Vámhivatal, adatok) és a felsőoktatási életpálya (Oktatási Hivatal FIR). A körülbelül 5 millió személy adatait tartalmazó országos adatbázisban (Admin3) egyszerre van lehetőség országos relevanciájú, ugyanakkor finomabb kutatási kérdések megválaszolására, valamint speciális kutatási kérdéseknek megfelelő alminták vizsgálatára.

\section{A kognitív készségek hozamának szakirodalma}

\section{A kognitív készségek}

A munkaerőpiaci helyzetet jellemzően az iskolai végzettséggel, a megszerzett munkatapasztalattal és különböző szociodemográfiai változókkal magyarázták a korai megtérülés- és hozamvizsgálatokban. További termelékenységet befolyásoló tényezők lehetnek azonban a kognitív és nem kognitív készségek és képességek, valamint személyiségjegyek is (Fazekas 2017). Éppen ezért az iskolarendszert vizsgáló megtérülési modellekben gyakran megjelennek a velünk született és tanult készségek, képességek mutatói, hiszen mint a termelékenység összetevői, befolyásolják az egyének által elérhető béreket és a munkaerőpiaci körülményeket is. Azonban ezek egy része csupán közvetetten figyelhető meg, míg más része (például a személyiségjegyek) nehezen vagy egyáltalán nem szerepeltethető társadalomtudományi modellekben. További mérési nehézséget okoz, hogy a fenti komponensek erősen korrelálnak a családi háttér, a lakókörnyezet, a referenciacsoport tulajdonságaival és az általános értelmi képességekkel is.

$\mathrm{A} z$ oktatási expanzióval megnőttek az oktatási beruházások, így egyre nagyobb számban jelentek meg az oktatás minőségét monitorozni kívánó központi, standardizált tesztek, melyek elsősorban a kognitív képességekre fókuszálnak. Az oktatás minőségét 
ezekkel az eszközökkel is csupán közvetetten lehet mérni, hiszen az eredményeket számos egyéb, iskolán kívüli tényező befolyásolja. Lazear (2003) munkája alapján ugyanakkor elmondható, hogy az általános intelligencia nem határozza meg teljes mértékben a későbbi munkapiaci eredményeket, hiszen a specifikus kognitív készségek tanuláson keresztül fejleszthetők (Hermann et al. 2019). Az így megszerzett specifikus kognitív képességek pedig számszerüsíthető előnyökkel járnak a munkaerőpiacon (Ritchie-BatesDeary 2015).

\section{A kognitív készségek hozama a munkaeröpiacon}

A kognitív szellemi képességek bevált proxy változója az IQ vagy a g érték. Ez utóbbit használva Murnane és szerzőtársai egy a hetvenes és a nyolcvanas évek középiskolai és felsőoktatási adatait felhasználó kutatásban arra jutottak, hogy a diplomás végzettséggel járó kereseti növekmény a képességekre kontrollálva a nők esetében eltünik, a férfiak esetében lecsökken (Murnane-Levy-Willet 1995). Hasonló eredményre jutott Blackburn és Neumark (1993) is. Svéd kutatási eredmények szerint a nem kognitív képességek a kereseti eloszlás alján és a szakképzetlen munkakörökben jelzik jól előre a relatív munkaerőpiaci sikerességet, míg a kognitív képességek a szakképzett dolgozók és a kereseti eloszlás tetején lévők bérét képesek jobban előjelezni (Lindqvist-Vestman 2011).

Egy korábbi magyar kutatásban az Országos kompetenciamérés (OKM) eredményeinek munkaerőpiaci hatását vizsgáltuk (Hermann et al. 2019), az eredmények szerint - az összes iskolai végzettséget megfigyelve - a 10. osztályos matematika kompetenciaeredmények szignifikánsan befolyásolják a későbbi munkaerőpiaci helyzetet. A magasabb végzettségüek esetében az egy szórással magasabb teszteredmény nagyobb keresetnövekményt eredményezett, míg az alacsonyabb végzettségűek körében jelentősen csökkentette a munkanélküliség valószínúségét. Ennek alapján az egyetemisták esetében a kompetenciakülönbségek elsősorban a bérek alakulására vannak hatással. Ugyanebben a vizsgálatban azt találtuk, hogy a diplomások körében a körülbelül egy szórással magasabb matematikateszt-pontszám 7-8 százalékkal növeli a kereseteket, az érettségizettek körében ez a hatás 1 százalék körüli, míg az alacsonyabb iskolázottságúak esetében 3 százalékos az eltérés.

A felsőoktatás és a munkaerőpiac kapcsolatát vizsgáló közgazdasági koncepciók egyik megközelítése a humántőke-elmélet, mely az oktatásban való részvételt hosszú távú beruházásnak tekinti, és megkülönbözteti annak egyéni és társadalmi oldalát (Becker 1975; Schultz 1960; Mincer 1958). Ebben a felfogásban az oktatási beruházás és az azzal együtt járó egyéni termelékenységnövekedés, egyéni és társadalmi szinten különböző, hosszú távon érvényesülő előnyökkel jár. Az egyén későbbi életében magasabb kereseteket és jobb munkakörülményeket realizálhat, míg társadalmi szempontból a képzettebb munkavállalók nagyobb mértékben növelik a gazdaság teljesítményét. Ebben a szemléletben született a munkapiaci megtérülés vizsgálatának egyik megközelítése, a kereseti függvények módszere. A széles körben használt Mincer-féle regresszió az iskolában eltöltött évek számát, a végzettség szintjét, a munkatapasztalatot és annak négyzetét használja a későbbi kereset becslésére (Mincer 1974). A függvénybe gyakran vonnak be a finomabb iskolai minőséget, az eredményességet mérő, valamint a közvetlenül iskolához nem köthető egyéb mutatókat. A kereseti függvények mint becslési módszerek hiányosságait elsősorban a kognitív és nem kognitív képességek és készségek eltéréseinek mérési 
nehézségei jelentik, hiszen ezek a tulajdonságok szerepet játszhatnak a továbbtanulás elkezdésében, a diploma megszerzésében és a magasabb keresetek elérésében is. Így e szempontok kihagyása a modellből felülbecsüli a megszerzett iskolai végzettség hatását (Gunderson-Oeropoulos 2010; Griliches 1977).

Hanushek (2009) az Egyesült Államok és a fejlődő országok kifejezetten - kognitív készségeket is tartalmazó - mincer-i regressziókat alkalmazó kutatásait gyűjtötte össze. Az USA-ban mért eredmények nagyjából konzisztensek voltak, az 1 szórással magasabb matematikai teszteredmény 12 százalékkal magasabb keresetekben tükröződött. Egyes kutatások arra is rámutattak, hogy különböző társadalmi csoportokban eltérően hatnak a korai teszteredmények (Tyler-Murnane-Willett 2000).

Egy ír kutatás mincer-i regressziók segítségével képzési területi bontásban vizsgálta a diplomások körében a felnőttkori kompetenciák bérekre gyakorolt hatását (KellyO’Connell-Smyth 2010). Eredményeik szerint egyes önbevalláson alapuló kompetenciaszintek (pl. technikai ismeretek) szignifikánsan hatottak a bérekre, míg mások nem mutattak vele szignifikáns összefüggést. A képzési területek közti eltérések e tekintetben nem bizonyultak szignifikánsnak adott módszertan használata mellett.

\section{A felsöoktatás hozama Magyarországon}

Magyarországon az 1990-es és a 2000-es évekre jellemző felsőoktatási expanzió 2012ben torpant meg. 2012-től kevesebben kerültek be a felsőoktatásba, így a diplomások részarányának csökkenése a fiatalok körében már 2015-től megfigyelhető.

A felsőfokú végzettség kereseti hozama kifejezetten magas Magyarországon: 2003 és 2016 között az általános iskolai végzettségüekhez képest a mester és osztatlan (egyetemi szintü) diplomások esetében végig 200-250 százalék körül mozgott. Az alapképzést (föiskolát) végzők kereseti hozama 130 és 160 százalék között alakult. Csupán a válság hatására érte el az alsó értéket mindkét esetben (Varga 2019a). Az eredmények tanúsága szerint nemzetközi összehasonlítás alapján is látható, hogy a magas szintű egyéni megtérülés abból adódik, hogy a diplomások száma még nem érte el a kereslet szintjét a magyar munkaerőpiacon. Varga kvantilis regressziók segítségével azt is vizsgálta, hogy a fiatal diplomások kereseti hozama hogyan alakult a kereseti eloszlás különböző csoportjaiban a 2006 és 2016 közötti időszakban (Varga 2019b). Eredményei szerint a magasabb jövedelmü csoportok hozama nem változott, míg a többi csoporté fokozatosan csökkent. A mesterképzésben végzettek esetében hasonló történt, ugyanakkor kisebb mértékü volt az elmozdulás. Ez alapján megállapítható, hogy elindult egy, a diplomás végzettséget érintő telítődési folyamat, ugyanakkor még kezdetleges szakaszban jár. Egy másik tanulmányban, szintén kvantilis regresszió segítségével Varga a képzési terület bérekre gyakorolt hatását vizsgálta a diplomások béreloszlásának különböző csoportjain (Varga 2013). Kontrollálva a családi háttérre és az intézményre a következő eredményekre jutott. A gazdaságtudomány és az informatika a jövedelemeloszlás minden pontján magasabb kereseteket eredményezett a jogi képzési területen végzettekhez képest. A jövedelemeloszlás alján a gazdaságtudományok képzési terület végzettjei jutottak a legmagasabb bérekhez, míg a diplomás béreloszlás tetején ez az informatika képzési területen végzettekre volt igaz. A pedagógusképzés területen végzettek lemaradása volt a legnagyobb a legmagasabb bércsoportban. 


\section{Adatok, változók}

Ez a tanulmány a Közgazdaság- és Regionális Tudományi Kutatóközpont Adatbankja által összeállított Kapcsolt Államigazgatási Adatbázison (Admin3) készült. Az Admin3 egyéni szinten, ugyanakkor anonimizált módon tartalmazza a 2003-as magyar népesség 50 százalékos mintájának a 2003 és 2017 közötti időszakra vonatkozó különböző adminisztratív adatait (Sebők 2019). Az adatbázisban munkaerőpiaci, egészségügyi, oktatási, kompetencia-, munkanélküliségi, munkáltatói és transzferadatok szerepelnek. A tanulmány alapjául szolgáló vizsgálat az oktatási, az Országos kompetenciamérési (OKM), a felsőoktatási hallgatói (OH FIR) és munkaerőpiaci életút, valamint a munkanélküliségi és GYES adatköröket használta.

A munkaerőpiaci megtérülés vizsgálata során a 2017 októberében jövedelemmel rendelkező foglalkoztatottakat vizsgáltam. Függő változónak az első és második munkaviszonyból származó bérek összegének természetes alapú logaritmusát tekintettem. Kimaradtak az elemzésből a közmunkások és a munkanélküliségi transzferben részesülők.

$\mathrm{A} z$ adatösszekötés lehetővé teszi az Országos kompetenciamérések (OKM) eredményeinek használatát is. A standardizált matematika- és szövegértéstesztek 2008-ra váltak közel teljes körűvé. Így az első érintett kohorsz az ebben az évben 10. osztályosok csoportja. Az ő oktatási és munkaerőpiaci pályájuk viszonylag hosszan, 9 éven át, 2017 ig követhető az adatbázisban. Az utolsó megfigyelési pillanatban már körülbelül 25 évesek a mintánkba tartozó fiatalok. Az OKM tartalmazza a családi hátteret leíró öszszetett változót, melyet a szülők iskolai végzettsége és a könyvek száma alapján kalkulálnak. Csak azok szerepelnek az elemzésben, akik legalább az egyik kompetenciatesztet megírták 2008-ban. A kompetenciamérésből származó tesztpontszám a legfontosabb magyarázó változók egyike. Az eredmények könnyebb interpretálhatósága érdekében a pontszámok és a családiháttér-index is standardizáltan (0 átlagú és 1 szórású változóvá alakítva) szerepelnek a modellben.

Szociodemográfiai kontrollként vontuk be a nemet, ugyanakkor a kort nem volt szükséges szerepeltetnünk a modellben, hiszen a 2008-ban 10. osztályos kompetenciatesztet írók életkora lényegében homogén.

$\mathrm{A} z$ adatbázis részletes adatokat tartalmaz az (Oktatási Hivatal FIR adatbázisban nyilvántartott) felsőoktatási végzettségekről is. Ennek alapján lehetséges volt a képzési szint pontos meghatározása és modellbe építése. A képzési területek megállapításakor szakpáros képzés esetén csak az első képzés képzési területét vettem számításba. A megfigyelt időpontra egyes hallgatók több alap- és mesterképzést is elvégeztek, így a végzettségi szint megállapításakor az alap-és mesterszintű végzettséggel is rendelkezőket a mesterképzésükkel szerepeltettük a modellben. Ha adott szinten több különböző képzési területen is végzett a hallgató, akkor minden egyes képzési területhez tartozó végzettségével szerepelt a modellekben. Ha egy képzési területen több azonos szintü végzettséget is szerzett, akkor csupán egyszer lett figyelembe véve a számítások során. A képzési területek vizsgálatakor a müvészetközvetítés terület adatait nem tüntetem fel, mivel kevés végzett szerepel a vizsgált mintánkban. Az egyszerűbb interpretálhatóság érdekében a részletesebb képzési információkat kihagytam a modellből (ilyenek a képzés, a munkarend és a finanszírozási forma). 


\section{Becslési eljárás}

A magyarországi vizsgálatok azt mutatják, hogy a kognitív készségek megtérülése munkanélküliség szempontjából a béreloszlás alján és az alacsonyabb iskolai végzettségek esetében különösen meghatározó (Hermann et al. 2019), így a diplomás alapsokaság miatt a klasszikus munkaerőpiaci kimeneti mutatók közül csak a keresetek vizsgálatával foglalkozom majd.

A tanulmányban a legösszetettebb (legtöbb változót tartalmazó) modell egyenlete az alábbi módon áll össze:

$$
\ln w_{i}=\beta_{1}+\beta_{2} G_{i}+\beta_{3} C_{i}+\beta_{4} F O S_{i}+\beta_{5} 5 L_{i}+\beta_{6} F_{i}+\beta_{7} P_{i}+\varepsilon_{i}
$$

Esetünkben a bérek természetes alapú logaritmusa a függő változó. A magyarázó változók pedig a nem $\left(G_{i}\right)$, a standardizált kompetencia szövegértés- és matematikatesztpontszámok $\left(C_{i}\right)$, a képzési terület dummy változószett $\left(F O S_{i}\right)$, a különböző képzési szinteket jelző változók $\left(L_{i}\right)$, a standardizált családiháttér-index $\left(F_{i}\right)$ és egy olyan kétértékű változó $\left(P_{i}\right)$, amely azt jelzi, hogy az egyén a piaci vagy a költségvetési szférában dolgozik-e. Minden más egyéb hatást a hibatag tartalmaz.

A nem bevonása indokolt volt a modellbe, mivel korábbi tanulmányokból ismert, hogy a férfiak szignifikánsan többet keresnek, és e hatás mértéke képzési területenként eltérő.

A kompetencia-pontszámoknak mint a kognitív készségek proxy változóinak modellbe vonása több szempontból korlátos. Egyfelől láttuk, hogy a mérési eszközök vitatott módon képesek megragadni a készségeket. Másfelől esetünkben a 2008-as 10. osztályos kompetencia-pontszámok jelen idejű hatása kétséges, hiszen azok mértéke, összetétele változhatott a megfigyelt 9 év során. Ezért jelen tanulmányban a felsőoktatás hozzáadott értékéről nem lehetséges szólni, mivel a termelékenységet proxyzó kompetenciapontszám-változó a középiskolás időszakból - nem a felsőoktatási belépés pillanatából - származik. Csupán arra tudok választ adni, hogy a felsőoktatási képzési szintek és képzési területek közti szelekció mennyire szigorú általános kognitív készségek szempontjából, valamint arra, hogy mekkora bérmegtérülésben fejeződik ki e készségek hatása.

A képzési terület strukturálisan meghatározza a munkaerőpiaci lehetőségeket, így a modellbe építése indokolt. A férfiak és nők közti bérszakadék egy részét a képzési területi választások nemenkénti különbségei magyarázzák: a fiúk nagyobb arányban tanulnak reál (STEM) területen, míg a lányok inkább a humán képzéseken vannak többségben.

A képzési szint szerepeltetése lényeges, hiszen egyfelől a magasabb kompetenciapontszámú hallgatók kisebb erőbefektetéssel érik el és szerzik meg a magasabb szintü végzettséget. Másrészt a megszerzett diploma szintje - a megszerezhető többlettudás miatt - is összefüggésben áll a termelékenységgel, ezáltal a bérek alakulásával.

A piaci és közszférát megkülönböztető kétértékü változóra azért van szükség, mert a közszféra munkaerőpiaca hagyományos keretek között nem értelmezhető, azaz nem a munkaerőpiaci kereslet-kínálati mechanizmusok határozzák meg a béreket, hanem a rögzített bértábla. Közszférán belül tehát kevéssé jellemzőek az egyéni készségek és képességek szerinti differenciált jövedelmek. 
A mincer-i regressziók egyik fő jellemzője, a munkaerőpiaci tapasztalat kimaradt a modellekből, hiszen a végzett sokaságunkban ugyanakkora a potenciális munkatapasztalat hossza, tekintve a felsőfokú tanulmányok alatti munkavállalás elterjedtségét.

A becslések első csoportjában az érettségizettek referenciacsoportjával vetem össze az alap- és a mesterképzéses végzettek keresetét, így a felsőoktatási végzettség egyéni hozamáról kapunk képet. A képzési terület ebben a modellben nem szerepel. A becslések második csoportjában a mintában csak a diplomások szerepelnek, de a képzési terület hatását itt nem vizsgálom. A harmadik csoport becslései megint csak a diplomások mintáját használja és a képzési terület hatását is vizsgálja a természettudomány referenciacsoportjához viszonyítva. Végül kvantilis regressziót alkalmazva, a jövedelmi eloszlás eltérő csoportjaiban külön-külön is megvizsgálom a kompetenciák megtérülését. Ennek során a fentebb részletezett egyenlethez tartozó, minden kontrollváltozót tartalmazó regressziós modell lett megismételve az alapképzéses diplomások jövedelemeloszlás szerinti alcsoportjaiban. Ebben az esetben szintén a természettudomány képzési terület a referencia, aminek viszonylatában az összes többi képzési területet vizsgálom.

\section{A kognitív készségek hatásának vizsgálata}

\section{Leíró statisztikák}

A megtérülési modellek eredményeinek ismertetése előtt érdemes áttekinteni a matematika- és szövegértéskompetencia-pontszámok alakulását a felsőoktatás különböző területein. Az 1. ábrán végzettségi és képzési szintenként mutatom be az átlagos kompetencia-pontszámokat. A pontszámok arról tanúskodnak, hogy a felsőfokú végzettség megszerzése felfogható kognitív képességek szerinti szelekcióként, akárcsak a még magasabb fokozatú osztatlan vagy mesterképzéses diploma elérése. A jobb képességü hallgatók számára alacsonyabb az egyetemi bekerülés és a felsőfokú végzettség megszer-

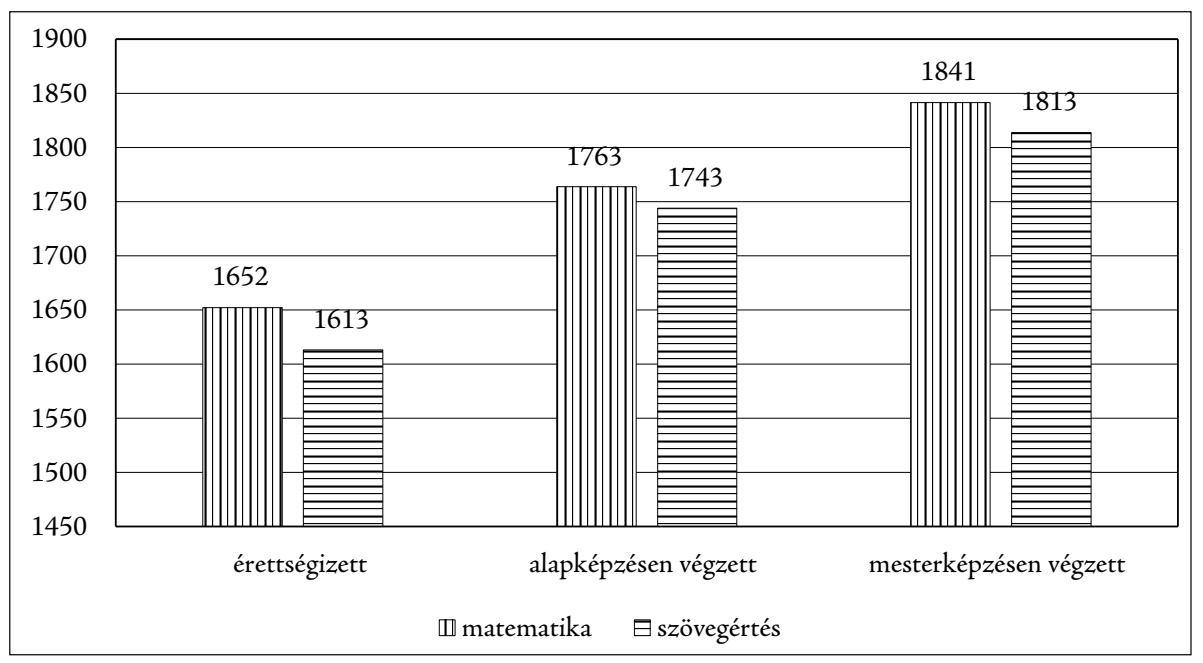

1. ábra: Az átlagos kompetencia-pontszám végzettségi és képzési szintenként.

Mintanagyság: 32466 statisztikai létszám. Forrás: Saját szerkesztés 
zésének költsége, hiszen kisebb erőbefektetést igényel a tanulmányi elvárások teljesítése. A felsőoktatási szelekció anyagi oldalát tekintve a hátrányosabb helyzetű hallgatók akiknek a kompetencia-pontszáma jellemzően alacsonyabb - kevésbé engedhetik meg maguknak a tanulmányok ideje alatti kieső jövedelmet, így kisebb arányban tanulnak tovább.

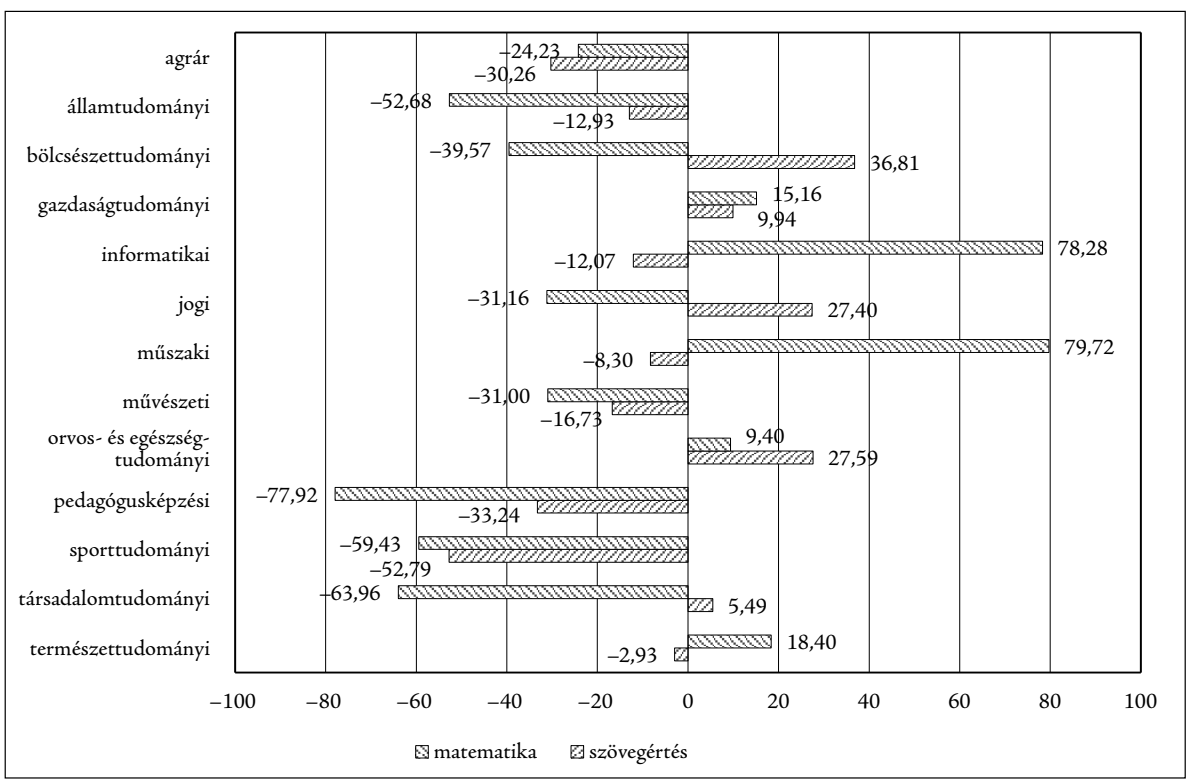

2. ábra: A diplomások átlagos kompetencia-pontszámától való átlagos eltérés, képzési területenként. Mintanagyság a szövegértés esetén: 13530 statisztikai létszám. Mintanagyság a matematika esetén: 13525 statisztikai létszám. Forrás: Saját szerkesztés.

A 2. ábrán a 2008-ban kompetenciatesztet írt, később alap-, mester- vagy osztatlan képzésen diplomázott hallgatók kompetenciaeredményei szerepelnek képzési területenként, a felsőfokú végzettséget szerzettek átlagos kompetenciaeredményeihez viszonyítva. Szövegértési kompetenciáikat tekintve a bölcsészettudomány végzettjei a legerősebbek, őket követik a jogi, illetve az orvos- és egészségtudomány terület diplomásai. A diplomás átlagnál magasabb kompetencia-pontszámmal rendelkeznek még a gazdaság- és a társadalomtudományi képzési területek végzettjei. A legalacsonyabb pontszámokkal a sporttudományi és a pedagógusképzés képzési területeken végzettek rendelkeznek. Átlag alatti összesített szövegértéspontszámot mutattak ezen felül a müszaki, az államtudományi, az informatikai, a művészeti, a természettudományi és az agrár képzési területek.

A matematikakompetencia-pontszámok szempontjából kiemelkednek a müszaki, az informatikai, a természettudományi, a gazdaságtudományok és az orvos- és egészségtudományi képzési területek. Minden további képzési terület átlag alatti összesített kompetencia-pontszámot mutat. Kiemelkedően alacsony matematikakompetenciaátlag tapasztalható a pedagógusképzés, a sporttudományi és a társadalomtudományi képzési területeken. A képzési területek kompetencia-pontszámai nem alakulnak meg- 
lepően, tekintve a képzési területekhez tartozó képzések felvételi követelményeit és azok későbbi szakmai profilját.

A következő, 3. ábrán az alapképzést végzett diplomások átlagos kompetencia-pontszámai láthatók nemenkénti bontásban. Látható, hogy a nők szövegértéspontszáma az orvos- és egészségtudomány és a pedagógusképzés képzési területek kivételével minden

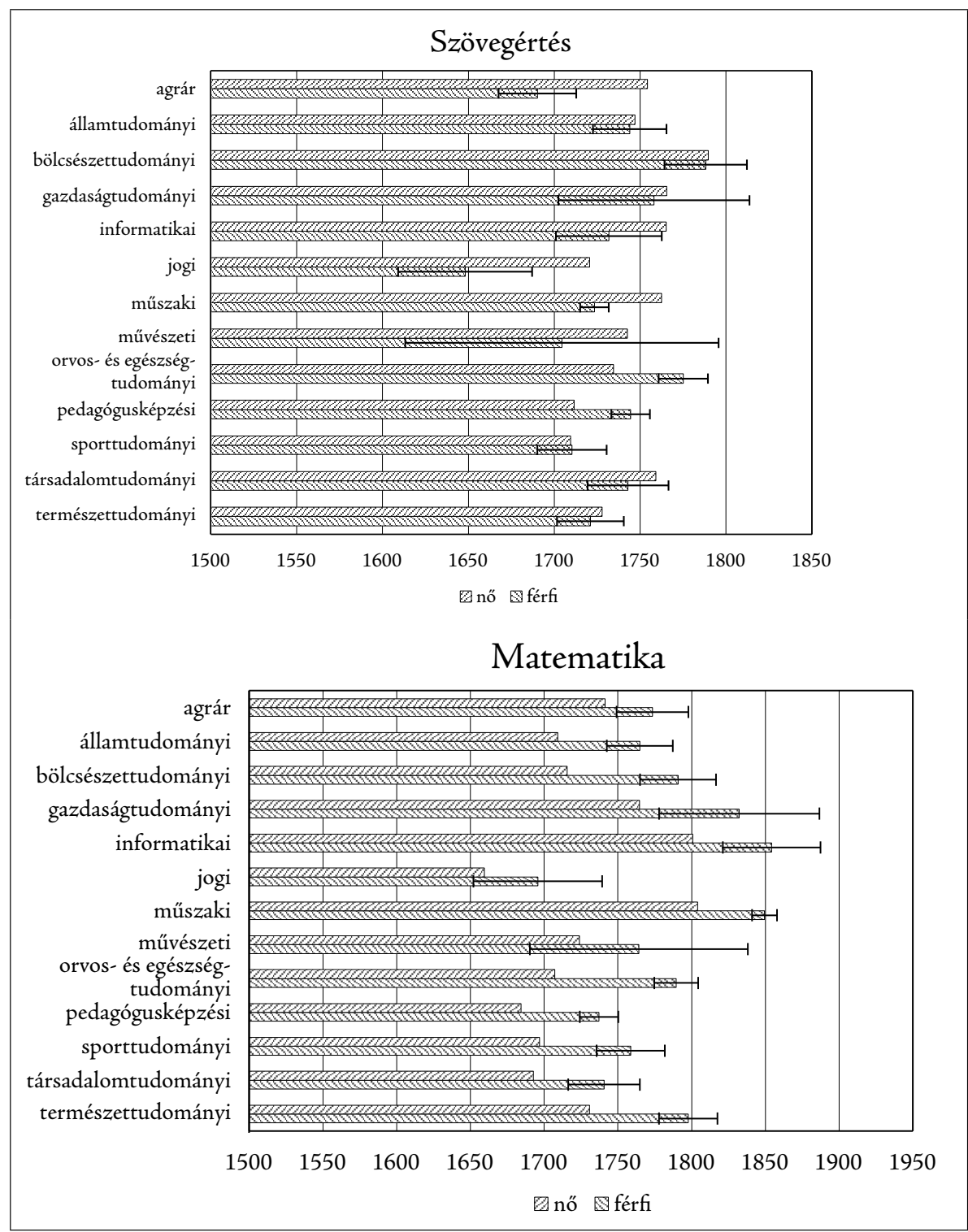

3. ábra: A alapképzést végzett diplomások átlagos kompetencia-pontszámai, nemenként és képzési területenként. Forrás: Saját szerkesztés. Mintanagyság a szövegértés esetén: 8456 statisztikai létszám. Mintanagyság a matematika esetén: 8454 statisztikai létszám. Az ábrán jelezve lett a férfiak átlagos kompetencia-pontszámához tartozó \pm 2 standard hiba 
képzési területen meghaladja a férfiak átlagpontszámait. Különösen igaz ez az agrár, informatika, jogi és müszaki területeken. Matematikateszt-pontszámok esetén a férfiak értek el jobb eredményeket szinte minden képzési területen. Ugyanakkor az adatok értelmezéséhez fontos megjegyezni, hogy a férfiak alacsonyabb arányban tanulnak tovább felsőoktatásban. Ennek oka, hogy számukra több olyan magasabb szintű iskolázottság nélkül is végezhető munkakör is elérhető, amit jellemzően férfiak végeznek.

\section{Kereseti modellek}

A következőkben a Mincer-féle kereseti modellek eredményeit mutatom be. Az első modellcsoportban (1. táblázat) a felsőoktatási képzési szintek megtérülése látható az érettségizettekhez viszonyítva. Az első modellben csak a nem magyarázza a bérek nagyságát. A teljes sokaság körében körülbelül 13 százalékkal többet keresnek a férfiak. A második modellben kontrollálva a végzettség szintjére, a nem hatása megnő a bérre vonatkozóan. Ez nem meglepő eredmény, tekintve, hogy a nők átlagosan magasabban kvalifikáltak, ugyanakkor az ugyanolyan végzettségü férfiak és nők között a nők keresnek kevesebbet. A 3. modellbe bekerültek magyarázó változóként a matematika- és a szövegértéskompetencia-teszt pontszámai. Mindkettő szignifikánsan hat a megszerezhető bérekre. Egy adott iskolai végzettség kategórián belül körülbelül az egy szórással magasabb matematikakompetencia-pontszám 6-7 százalékkal növeli a béreket, míg a szövegértés-pontszámok hatása kevésbé érvényesül. Utóbbi esetben körülbelül 2-3 százalékos eltérést jelent a bérekben az 1 szórásnyi pontszámeltolódás. A nem hatása lecsökkenni látszik, hiszen a férfiak magasabb kompetencia-pontszámmal rendelkeznek, ami részben megmagyarázza a nemek közötti bérszakadékot. A családi háttér hatása nem tekinthető szignifikánsnak a korábban bevont kontrollokat követően. Az ötödik modellben látható, hogy az ugyanolyan végzettségi és kompetenciaszinttel rendelkező fiatalok esetében a piaci szféra nagyjából 8 százalékos bérprémiumot jelent a közszférához képest, mivel az utóbbi bértáblarendszere kevésbé rugalmas, így nem képes lekövetni az egyéni termelékenységi különbségeket, valamint a pályakezdőkhöz különösen alacsony béreket rendel.

A diploma kompetencia-pontszámokra kontrollált bérhozama - figyelembe véve a fent említett egyéb háttérváltozókat is - az érettségihez képest alapképzés esetén körülbelül 26 százalék, mesterképzés esetén 34-35 százalék a végső modellben. Azonban az eredmények értelmezéséhez fontos megjegyezni, hogy a mesterképzéses diploma megszerzésétől átlagosan kevesebb potenciális szakterületi munkavégzésre alkalmas idő telt el a megfigyelés 2017. októberi időpontjáig, mint az alapképzéses végzettség megszerzését követően. Így, mivel nem vettük számításba a képzési szintekhez tartozó eltérő potenciális munkaerőpiaci tapasztalatot, ez az érték a mesterképzéses végzettség hozamának alsó becslése.

A 2. táblázat egy szűkebb, csupán a diplomásokat tartalmazó minta felhasználásával készült becslések eredményeit mutatja. A diplomások körében kifejezetten nagymértékü a nemek közötti bérkülönbség még a képzési szintekre kontrollált modellek tanúsága szerint is. A kompetencia-pontszámok bevonását követően a nemek által magyarázott bérkülönbség lecsökken körülbelül 15-16 százalékos szintre. A diplomások körében az egy szórással magasabb matematikakompetencia-pontszám körülbelül 9-10 százalékkal növelte meg a béreket, míg a szövegértéspontszám ugyanilyen mértékű változása 
1. táblázat: A 10. osztályos kompetencia-pontszámok hatása a felnőttkori keresetekre az érettségizettek és a diplomások körében

\begin{tabular}{lccccc}
\hline & 1. modell & 2. modell & 3. modell & 4. modell & 5. modell \\
\hline Férfi (ref. nő) & $0,135^{* * *}$ & $0,196^{* * *}$ & $0,166^{* * *}$ & $0,166^{* * *}$ & $0,161^{* * *}$ \\
& $(0,0101)$ & $(0,00989)$ & $(0,0106)$ & $(0,0106)$ & $(0,0106)$ \\
\hline Mester (ref. érettségi) & & $0,436^{* * *}$ & $0,326^{* * *}$ & $0,331^{* * *}$ & $0,346^{* * *}$ \\
& & $(0,0138)$ & $(0,0158)$ & $(0,0163)$ & $(0,0164)$ \\
\hline Alap (ref. érettségi) & & $0,318^{* * *}$ & $0,250^{* * *}$ & $0,253^{* * *}$ & $0,263^{* * *}$ \\
& & $(0,0114)$ & $(0,0123)$ & $(0,0126)$ & $(0,0126)$ \\
\hline Matematika & & $0,0649^{* * *}$ & $0,0660^{* * *}$ & $0,0626^{* * *}$ \\
& & & $(0,00710)$ & $(0,00714)$ & $(0,00715)$ \\
\hline Szövegértés & & $0,0262^{* * *}$ & $0,0273^{* * *}$ & $0,0284^{* * *}$ \\
& & & $(0,00682)$ & $(0,00687)$ & $(0,00686)$ \\
\hline Családi háttér & & & $-0,00745$ & $-0,00811$ \\
& & & & $(0,00562)$ & $(0,00561)$ \\
\hline Piaci szféra (ref. & & & & & $0,0883^{* * *}$ \\
közszféra) & & & & & $(0,0130)$ \\
\hline Konstans & $12,16^{* * *}$ & $11,97^{* * *}$ & $12,03^{* * *}$ & $12,03^{* * *}$ & $11,95^{* * *}$ \\
& $(0,00694)$ & $(0,00844)$ & $(0,00948)$ & $(0,00975)$ & $(0,0148)$ \\
\hline$R^{2}$ & 0,011 & 0,089 & 0,100 & 0,101 & 0,103 \\
\hline
\end{tabular}

Mintanagyság: 16172 statisztikai létszám. Az érettségizett foglalkoztatottak, valamint az alap, mester- és osztatlan képzésen végzett, foglalkoztatott diplomások - a felsőfokú szakképzést és felsőoktatási szakképzést szerzettek -, valamint az egyéb szinteken diplomát szerzettek kimaradtak a modellből. Forrás: Saját szerkesztés

A jelölések az alábbi módon értelmezhetők: ${ }^{* *} p<0,01,{ }^{* *} p<0,05,{ }^{*} p<0,1$. A standard hibák a zárójelekben szerepelnek

csupán 3-4 százalékot mozdít a béreken. Ennek egyik oka a tudásintenzív, elsősorban technológiai tudást igénylő munkakörök iránti nagy kereslet, mely szféra kereseteitől a szövegértési kompetenciákat igénylő, tisztán humán munkakörök bérezése elmarad. A piaci szféra a diplomások körében körülbelül 14 százalékos bérnövekményt mutat a közszférához képest. Eszerint a hasonló képességü, végzettségi szintü és azonos nemü diplomások 14 százalékkal keresnek kevesebbet a közszférában, ami felveti a kérdést, hogy milyen egyéb, nem megfigyelt vonások alapján, milyen mechanizmusok mentén választják a diplomások a közszférát. Ilyen köztes dimenzió lehet a kezdeti alacsony béreket kompenzáló életpályamodell, a kevésbé versengő munkahelyi közeg, a munkaviszony biztonsága, a különböző munkaviszonnyal járó kedvezmények vagy az egyén számára élvezetes, érdekes, esetleg hasznos feladatok.

A harmadik modellcsoport becsléseit szintén az alap-, mester- és osztatlan diplomások mintáján végeztem (3. táblázat). Az eredmények alapján elmondható, hogy a képzési terület bevonásával a nem bérre gyakorolt hatása 10 százalékra csökken. Tehát a nemek 
2. táblázat: A 10. osztályos kompetencia-pontszámok hatása a felnőttkori keresetekre a diplomások körében

\begin{tabular}{lccccc}
\hline & 1 modell & 2. modell & 3. modell & 4 . modell & 5. modell \\
\hline Férfi (ref. nő) & $0,203^{* * *}$ & $0,201^{* * *}$ & $0,155^{* * *}$ & $0,156^{* * *}$ & $0,142^{* * *}$ \\
& $(0,0149)$ & $(0,0149)$ & $(0,0158)$ & $(0,0158)$ & $(0,0158)$ \\
\hline Mester (ref. alap) & & $0,118^{\star * *}$ & $0,0565^{* * *}$ & $0,0594^{* * *}$ & $0,0706^{* * *}$ \\
& & $(0,0149)$ & $(0,0154)$ & $(0,0156)$ & $(0,0156)$ \\
\hline Matematika & & $0,0976^{* * *}$ & $0,0994^{* * *}$ & $0,0916^{* * *}$ \\
& & & $(0,0101)$ & $(0,0102)$ & $(0,0102)$ \\
\hline Szövegértés & & $0,0352^{* * *}$ & $0,0367^{* * *}$ & $0,0384^{* * *}$ \\
& & & $(0,0107)$ & $(0,0108)$ & $(0,0107)$ \\
\hline Családi háttér & & & $-0,0120$ & $-0,0154^{*}$ \\
& & & & $(0,00859)$ & $(0,00856)$ \\
\hline Piaci szféra (ref. & & & & $0,136^{* * *}$ \\
közszféra) & & & & & $(0,0170)$ \\
\hline Kontans & $12,33^{* * *}$ & $12,29^{* * *}$ & $12,28^{* * *}$ & $12,28^{* * *}$ & $12,18^{* * *}$ \\
& $(0,00911)$ & $(0,0105)$ & $(0,0108)$ & $(0,0109)$ & $(0,0165)$ \\
\hline$R^{2}$ & 0,025 & 0,034 & 0,059 & 0,059 & 0,068 \\
\hline
\end{tabular}

Mintanagyság: 7153 statisztikai létszám, az alap-, mester- és osztatlan képzésen végzett, foglalkoztatott diplomások. Forrás: Saját szerkesztés

A jelölések az alábbi módon értelmezhetők: ${ }^{* * *} p<0,01,{ }^{* *} p<0,05,{ }^{*} p<0,1$. A standard hibák a zárójelekben szerepelnek

közötti bérkülönbségek nagy részét megmagyarázza a nemek közötti képzési területi szelekció: az a döntés, hogy a férfiak és a nők jellemzően mely képzési területeket választják. A képzési területek majdnem mindegyike szignifikáns hatással van a bérek alakulására. A természettudományi képzési területhez képest az államtudományi, a bölcsészettudományi, a gazdaságtudományi, az informatikai és a müszaki képzési területek pozitívan hatnak a bérekre, míg a müvészet, a pedagógusképzés, a sporttudomány és az agrár területek alacsonyabb béreket eredményeznek. Érdekes eredmény, hogy a két kompetenciapontszám-típus hatása a képzési terület kontroll alatt tartásával kiegyenlítődik, tehát adott képzési területen végzettek esetében ugyanannyit - körülbelül 4-5 százalékot - jelent a bérekben a szövegértés- és a matematika-pontszám egy szórásnyi elmozdulása. Az azonos képzési területen végzettek között már nincs szignifikáns hatása a bérekre annak, hogy valaki a piacon vagy a közszférában dolgozik. Ez abból következik, hogy egyes képzési területek végzettjei jellemzően a piacon, míg másoké a közszférában helyezkednek el. Az előbbi, 2. táblázatban látható nagymértékű jövedelemkülönbség a két szféra között tehát nem feltétlen a képességkülönbségek miatt alakul ki, hanem a képzési területek munkapiaci sajátosságaiból adódik.

A családi háttér egyik modellben sem szignifikáns, azaz a diploma megszerzése, a kompetenciaeredmény és a képzési terület kiválasztása már magában hordozza a családi 


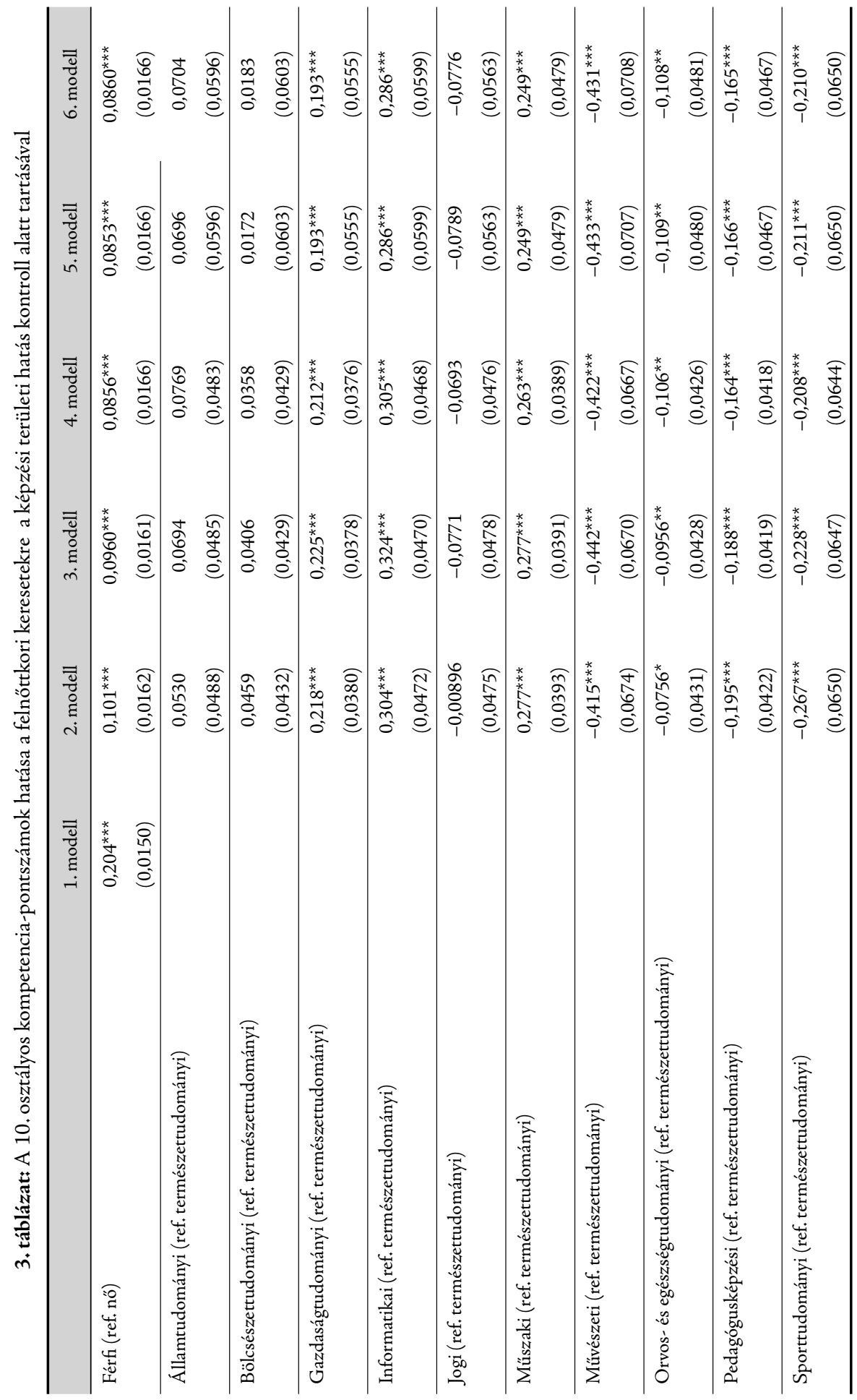




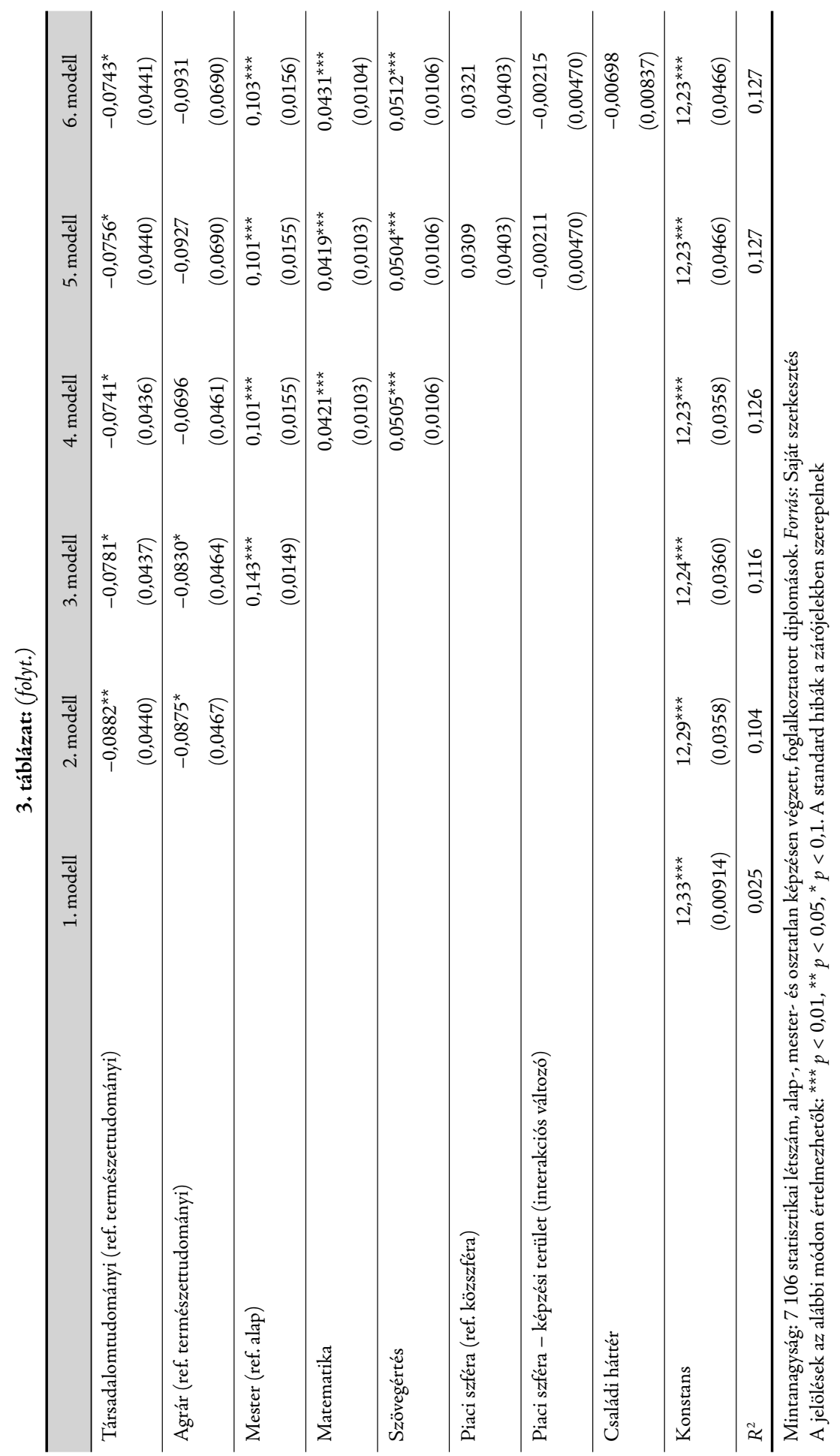


háttér okozta különbségeket, így ezek kontroll alatt tartásával a családi háttér már nem hordoz többletinformációt egyik modellben sem a bérekre nézve.

A következő modellcsoportban (4. táblázat) az eddigi összes kontrollt tartalmazó becslést ismételtem meg a jövedelemeloszlás különböző pontjain, kizárólag az alapképzést végzettek körében. Így megválaszolható, hogy az azonos tulajdonságú diplomások esetében eltérően hat-e a kompetencia-pontszám a különböző kereseti csoportokban.

A nem egyedül a legalacsonyabb jövedelemcsoportban nem hat szignifikánsan a bérek alakulására, ugyanakkor egyre inkább hat a magasabb jövedelmi csoportok irányába haladva, azaz a jövedelmek emelkedésével a nemek közötti jövedelmi olló egyre inkább szétnyílik.

A matematika és a szövegértés tesztpontszámainak hatása nem érvényesül a legalacsonyabb jövedelmi csoportban, azonban a magasabb percentilisekben hatásuk mértéke fokozatosan növekszik.

A következőkben azt ismertetem, hogy az ugyanolyan képességű és nemű alapképzéses diplomások kereseteire milyen hatással van az általuk elvégzett képzés képzési területe a különböző jövedelmi csoportokban. Az államtudományi képzési terület végzettjei minden jövedelmi csoportban többet keresnek a referencia képzési területként megjelölt természettudományok képzési terület végzettjeinél, a képzési terület hatása a 75. és a 90. jövedelmi percentilisben szignifikáns is. A bölcsészettudományi végzettség hatása csupán a legmagasabb jövedelmi csoportban látható, ahol keresetük körülbelül 24 százalékkal magasabb a természettudósokéhoz képest. A pedagógus képzési területen végzettek keresete szignifikánsan alacsonyabb a medián feletti jövedelmi csoportokban, mint a hasonló képességű természettudósoké. Az informatika és a müszaki képzési területen végzettek a jövedelemeloszlás minden pontján szignifikánsan többet keresnek a hasonló kompetencia-pontszámmal rendelkező természettudósoknál. A béreloszlás minden pontján a hasonló kompetencia-pontszámmal rendelkező diplomások bérét leginkább az informatika képzési terület emeli meg, 26-43 százalék közötti bércsoportonkénti átlagos hozammal a természettudományi végzettségű diplomásokhoz képest. A z eloszlás minden pontján viszonylag magas hozamot mutatnak a műszaki képzési területen végzettek (körülbelül 24-28 százalékos bérprémium a referenciakategóriához képest). A legfelső decilisben ennek mértékét azonban meghaladja a gazdaságtudományok terület diplomásainak bérprémiuma, akiknek bére átlagosan 32 százalékkal haladja meg a referenciacsoportét. A képzési területen szerzett végzettség minden jövedelmi csoportban magasabb béreket eredményez a referenciacsoporténál, ugyanakkor csak az 50. percentilis felett látható szignifikáns hatás.

$\mathrm{A} z$ előző táblázatban látható volt, hogy a magasabb jövedelmi csoportokban keresnek legnagyobb mértékben többet a férfiak, mint a nők. Most lássuk, hogy miként alakul a kompetencia-pontszámok hatása nemenként a különböző jövedelemcsoportokban. A kvantilis regressziós becsléseket megismételtem külön a nők és külön a férfiak csoportjában. Látható, hogy minden eddigi háttérváltozóra kontrollálva mind a matematika-, mind a szövegértéspontszámok kisebb hatást gyakoroltak a nők kereseteire a jövedelemeloszlás majd minden pontján. Tehát esetükben a meglévő kognitív készségek szintje kisebb mértékben hat a bérek alakulására, helyette más szempontok a hangsúlyosabbak. Ennek a nem megfigyelt szempontnak a vizsgálata további kutatás tárgyát képezi. A matematikapontszámok kevéssé hatnak bérekre a jövedelemeloszlás két végén a férfiak esetén, míg a nők körében a magasabb jövedelmi csoportok irányába fokozato- 
4. táblázat: A 10. osztályos kompetencia-pontszámok hatása a felnőttkori keresetekre a jövedelemeloszlás különböző pontjain

\begin{tabular}{|c|c|c|c|c|}
\hline & 25. percentilis & 50. percentilis & 75. percentilis & 90. percentilis \\
\hline \multirow[t]{2}{*}{ Férfi (ref. nő) } & 0,0169 & $0,0730^{* * *}$ & $0,112^{* * *}$ & $0,157^{* * *}$ \\
\hline & $(0,0285)$ & $(0,0213)$ & $(0,0185)$ & $(0,0221)$ \\
\hline \multirow[t]{2}{*}{$\begin{array}{l}\text { Államtudományi (ref. } \\
\text { természettudományi) }\end{array}$} & 0,0112 & 0,0711 & $0,136^{\star *}$ & $0,240^{\star * *}$ \\
\hline & $(0,0936)$ & $(0,0698)$ & $(0,0609)$ & $(0,0726)$ \\
\hline \multirow[t]{2}{*}{$\begin{array}{l}\text { Bölcsészettudományi (ref. } \\
\text { természettudományi) }\end{array}$} & $-0,00999$ & $-0,0587$ & 0,102 & $0,239^{* * *}$ \\
\hline & $(0,0985)$ & $(0,0735)$ & $(0,0641)$ & $(0,0764)$ \\
\hline \multirow[t]{2}{*}{$\begin{array}{l}\text { Gazdaságtudományi (ref. } \\
\text { természettudományi) }\end{array}$} & 0,0707 & $0,112^{*}$ & $0,160^{\star \star \star}$ & $0,324^{\star * *}$ \\
\hline & $(0,0891)$ & $(0,0665)$ & $(0,0580)$ & $(0,0692)$ \\
\hline \multirow[t]{2}{*}{$\begin{array}{l}\text { Informatikai (ref. } \\
\text { természettudományi) }\end{array}$} & $0,264^{* * *}$ & $0,256^{\star * *}$ & $0,339^{* * *}$ & $0,436^{\star * *}$ \\
\hline & $(0,0943)$ & $(0,0704)$ & $(0,0614)$ & $(0,0732)$ \\
\hline \multirow[t]{2}{*}{$\begin{array}{l}\text { Jogi (ref. } \\
\text { természettudományi) }\end{array}$} & 0,0581 & 0,0402 & 0,0695 & $0,193^{* *}$ \\
\hline & $(0,125)$ & $(0,0931)$ & $(0,0812)$ & $(0,0969)$ \\
\hline \multirow[t]{2}{*}{$\begin{array}{l}\text { Műszaki (ref. } \\
\text { természettudományi) }\end{array}$} & $0,243^{* * *}$ & $0,182^{\star * *}$ & $0,212^{* * *}$ & $0,281^{\star * *}$ \\
\hline & $(0,0774)$ & $(0,0577)$ & $(0,0504)$ & $(0,0601)$ \\
\hline \multirow[t]{2}{*}{$\begin{array}{l}\text { Művészeti (ref. } \\
\text { természettudományi) }\end{array}$} & $-0,498^{\star * *}$ & $-0,236^{* *}$ & $-0,0385$ & 0,0265 \\
\hline & $(0,128)$ & $(0,0956)$ & $(0,0834)$ & $(0,0995)$ \\
\hline \multirow{2}{*}{$\begin{array}{l}\text { Orvos- és egészségtudo- } \\
\text { mányi (ref. természet- } \\
\text { tudományi) }\end{array}$} & $-0,0378$ & $-0,0628$ & $-0,0153$ & 0,0482 \\
\hline & $(0,0792)$ & $(0,0590)$ & $(0,0515)$ & $(0,0614)$ \\
\hline \multirow[t]{2}{*}{$\begin{array}{l}\text { Pedagógusképzési (ref. } \\
\text { természettudományi) }\end{array}$} & $-0,0118$ & $-0,149^{* * *}$ & $-0,171^{\star * *}$ & $-0,160^{\star * *}$ \\
\hline & $(0,0752)$ & $(0,0560)$ & $(0,0489)$ & $(0,0583)$ \\
\hline \multirow[t]{2}{*}{$\begin{array}{l}\text { Sporttudományi (ref. } \\
\text { természettudományi) }\end{array}$} & $-0,205^{\star *}$ & $-0,228^{\star * *}$ & $-0,0593$ & $-0,0227$ \\
\hline & $(0,0927)$ & $(0,0691)$ & $(0,0603)$ & $(0,0719)$ \\
\hline \multirow[t]{2}{*}{$\begin{array}{l}\text { Társadalomtudományi (ref. } \\
\text { természettudományi) }\end{array}$} & $-0,0471$ & $-0,0691$ & $-0,0592$ & $-0,0558$ \\
\hline & $(0,0693)$ & $(0,0517)$ & $(0,0451)$ & $(0,0538)$ \\
\hline
\end{tabular}


4, táblázat: (folyt.)

\begin{tabular}{|c|c|c|c|c|}
\hline & 25. percentilis & 50. percentilis & 75. percentilis & 90. percentilis \\
\hline \multirow[t]{2}{*}{$\begin{array}{l}\text { Agrár (ref. } \\
\text { természettudományi) }\end{array}$} & $-0,0904$ & $-0,242^{\star * *}$ & $-0,121^{*}$ & $0,175^{\star *}$ \\
\hline & $(0,110)$ & $(0,0820)$ & $(0,0715)$ & $(0,0853)$ \\
\hline \multirow[t]{2}{*}{ Matematika } & 0,0129 & $0,0345^{* *}$ & $0,0539^{* * *}$ & $0,0589^{* * *}$ \\
\hline & $(0,0214)$ & $(0,0159)$ & $(0,0139)$ & $(0,0166)$ \\
\hline \multirow[t]{2}{*}{ Szövegértés } & 0,0347 & $0,0429^{\star * *}$ & $0,0466^{* * *}$ & $0,0574^{* * *}$ \\
\hline & $(0,0212)$ & $(0,0158)$ & $(0,0138)$ & $(0,0164)$ \\
\hline \multirow[t]{2}{*}{$\begin{array}{l}\text { Matematika - nem } \\
\text { (interakciós változó) }\end{array}$} & 0,0182 & $0,0582^{\star *}$ & 0,0174 & $-0,0176$ \\
\hline & $(0,0331)$ & $(0,0247)$ & $(0,0216)$ & $(0,0257)$ \\
\hline \multirow[t]{2}{*}{$\begin{array}{l}\text { Szövegértés - nem } \\
\text { (interakciós változó) }\end{array}$} & 0,0460 & 0,00442 & 0,0105 & 0,0125 \\
\hline & $(0,0338)$ & $(0,0252)$ & $(0,0220)$ & $(0,0262)$ \\
\hline \multirow[t]{2}{*}{ Piaci szféra (ref. közszféra) } & $-0,0300$ & $0,147^{* * *}$ & $0,172^{\star * *}$ & $-0,00243$ \\
\hline & $(0,0652)$ & $(0,0487)$ & $(0,0424)$ & $(0,0506)$ \\
\hline \multirow[t]{2}{*}{$\begin{array}{l}\text { Piaci szféra - képzési } \\
\text { terület (interakciós változó) }\end{array}$} & $-0,00564$ & $-0,0116^{* *}$ & $-0,00598$ & $0,0150^{* * *}$ \\
\hline & $(0,00746)$ & $(0,00556)$ & $(0,00485)$ & $(0,00579)$ \\
\hline \multirow[t]{2}{*}{ Családi háttér } & 0,00108 & $0,0165^{*}$ & $0,0283^{* * *}$ & $0,0313^{* * *}$ \\
\hline & $(0,0134)$ & $(0,0100)$ & $(0,00874)$ & $(0,0104)$ \\
\hline \multirow[t]{2}{*}{ Konstans } & $12,09^{* * *}$ & $12,31^{\star * *}$ & $12,46^{* * *}$ & $12,60^{* * *}$ \\
\hline & $(0,0750)$ & $(0,0559)$ & $(0,0488)$ & $(0,0582)$ \\
\hline
\end{tabular}

Mintanagyság: 4505 statisztikai létszám, alapképzésen végzett, foglalkoztatott diplomások.

Forrás: Saját szerkesztés

A jelölések az alábbi módon értelmezhetők: ${ }^{* *} p<0,01,{ }^{* *} p<0,05,{ }^{*} p<0,1$. A standard hibák a zárójelekben szerepelnek

san nő, majd stagnál a tesztpontszámok hatása. A szövegértés kompetenciaeredmények bérkülönbségekre gyakorolt hatása az 50. percentilistől (a bérmediántól) felfelé fokozatosan növekszik mindkét nem esetében. A legalacsonyabb bércsoportban ugyanakkor a férfiak esetén kiugró, 8,97 százalékos hatás látható. Ez abból adódhat, hogy a férfiak ebben a jövedelemcsoportban jellemzően alacsony matematikakompetencia-pontszámmal rendelkeznek.

\section{Következtetések}

Magyarországon nemzetközi viszonylatban is magas a felsőoktatás és az alapképzést követő mesterképzés bérprémiuma. Eredményeink alapján látható, hogy az iskolai végzettségek és szintek közti hozamkülönbségek egy részét a korai kognitív képességek meg- 


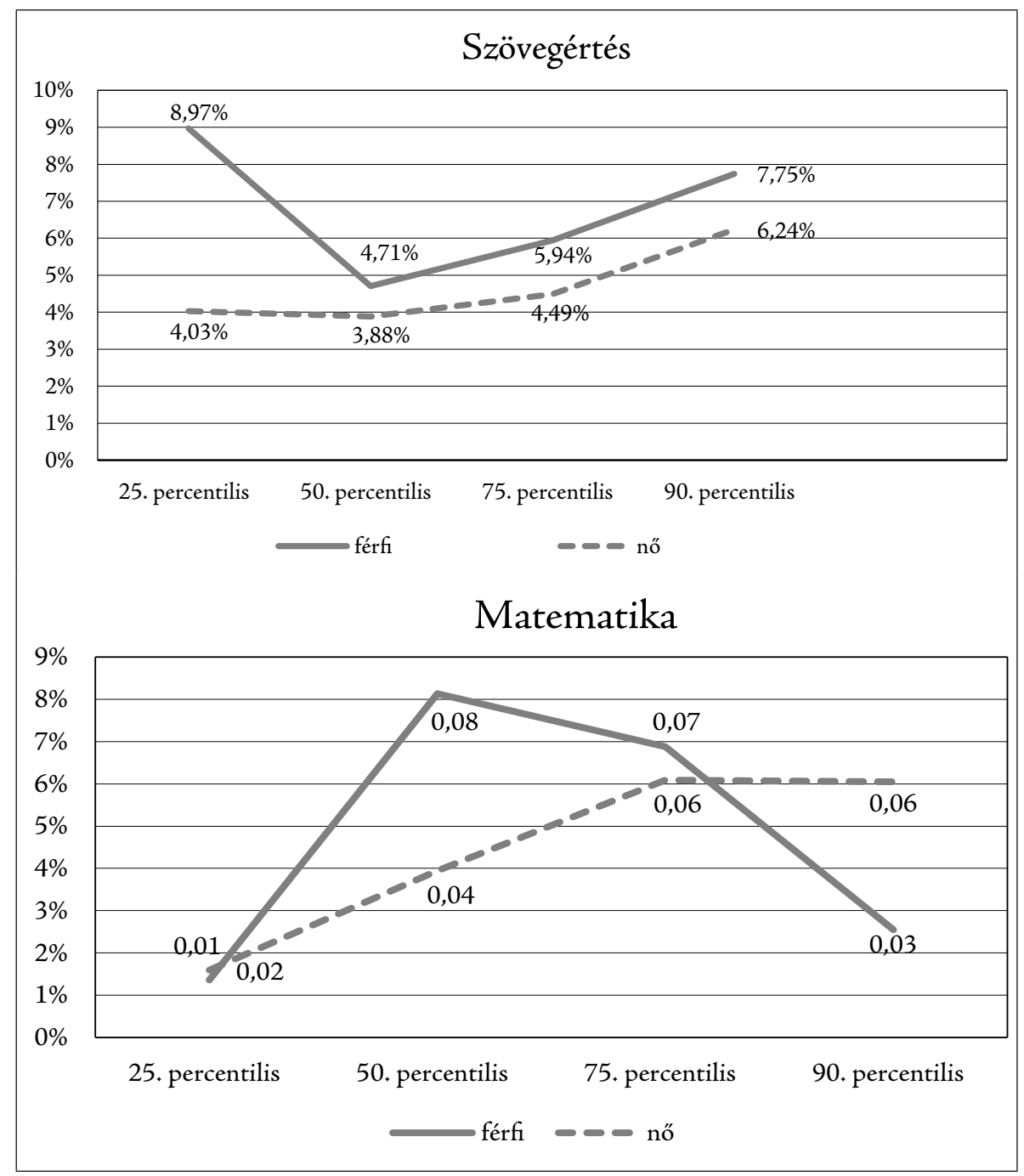

4. ábra: A matematika- és a szövegértéspontszámok hatása a bérekre a jövedelemeloszlás különböző pontjain, nemenként. Forrás: Saját szerkesztés. Mintanagyság: 4505 statisztikai létszám, alapképzésen végzett, foglalkoztatott diplomások

magyarázzák. Tehát a már középiskolás korban jobban teljesítők szereznek később diplomát vagy lépnek tovább a magasabb képzési szintre.

A diplomások körében a különböző képzési területeken végzettek átlagos kompetencia-pontszáma jelentősen eltérő. A matematikakompetencia-pontszám szempontjából átlag feletti képességűek az informatikai, a müszaki, a gazdaságtudományi, a természettudományi és az orvos- és egészségtudományi végzettek, míg szövegértési kompetenciáikat tekintve eredményesebbek a bölcsészettudományi, a gazdaságtudományi, az orvos- és egészségtudományi, a jogi és a társadalomtudományi képzési területek diplomásai. Az átlagosnál jelentősen rosszabb kompetencia-pontszámmal rendelkeztek 
mindkét felméréstípusban a pedagógusképzés és a sporttudomány képzési területeken végzettek.

A diplomások körében az egy szórással magasabb 10. osztályos matematikakompetencia-pontszám körülbelül 9 százalékkal növeli meg a béreket, míg ugyanennyi eltérés a szövegértési pontszámok esetében csupán 4 százalékos eltérést eredményez. Ez a kompetenciatípusok közötti hatáskülönbség mérséklődik, amint az ugyanolyan nemü, ugyanazon képzési területen végzett, azonos szférában dolgozó diplomások között vizsgálódunk. Tehát kontrollálva ezen tulajdonságokra az olvasás- és a matematikakompetenciák képzési területeken belüli átlagos hozama kiegyenlítődik, közel ugyanannyira hat az elérhető bérekre. Ez a megállapítás kiterjeszthető a béreloszlás bármely pontjára, azonban egyre magasabb bércsoportok felé haladva fokozatosan növekszik a hatásuk mértéke.

A z elemzésből kiderült, hogy az elérhető bérek szempontjából a nők esetében kisebb a jelentősége a kognitív készségeknek. Kivételt képez ez alól a matematikakompetenciák hatása a legmagasabb jövedelműek kategóriájában, ahol az egy szórással magasabb kompetencia-pontszám a férfiak esetén csupán 2,5 százalékkal, a nők körében azonban 6 százalékkal növeli meg a béreket.

A felsőoktatási képzések közötti hozamkülönbségeket ugyanakkor nem csupán az eltérő kompetencia-összetétel okozza, hanem a képzési területi választás és a képzési területenként eltérő munkaerőpiaci körülmények is. Ezt támasztja alá, amit a kvantilis regresszió (4. táblázat) alapú modellekben láthattunk: a hasonló családi hátterű, hasonló 10. osztályos kompetencia-pontszámot elért diplomások közül egyes képzéseken - jellemzően az informatikai, a müszaki és a gazdaságtudományi területeken - a jövedelemeloszlás minden pontján lényegesen jobban keresnek a végzettek a többi képzési terület diplomásaihoz viszonyítva. A felsőoktatási megtérülés- és hozamkutatások azonban korlátozottan tudják bevonni a megtérülés egyéb szempontjait. Ilyenek lehetnek például a jobb, rugalmasabb munkakörülmények, az egyén számára érdekesebb munkakör és egyéb nehezen kvantifikálható dimenziók. Természetesen így a felsőoktatási képzés irányának megválasztása nem fordítható le csupán a magasabb jövedelem elérését célzó döntésként, ugyanakkor nagy hatással van a későbbi keresetekre.

A modellek egyik közvetett eredménye, hogy a előnytelenebb családi hátterű tanulók rosszabb kompetencia-pontszámot értek el és később alacsonyabb bérezésű képzési területet választottak. Tehát a közoktatási rendszer csak kis mértékben képes csökkenteni az eleve meglévő társadalmi különbségeket. Ugyanakkor az is látszik, hogy a középiskolai kompetencia-pontszámok jelentős mértékben vetítik előre a későbbi béreket, tehát ebből a szempontból is fontos a közoktatás minőségének javítása. A közoktatási rendszer megújításának kulcskérdése a pedagógusképzés. A pedagógusképzést végzettek alacsony kompetenciaszinttel rendelkeznek mind matematikából, mind szövegértésből, ami további problémákat vet fel a magyar oktatási rendszer jelenlegi helyzetével kapcsolatban. Az állami és a piaci szféra közti valós készségektől független pályakezdő bérszakadék pedig a jövőjét illetően is aggasztó. A pedagógus munkakör jutalma többek között, a nem mérhető, ugyanakkor fontos megtérülési dimenzió az az intellektuális kihívás lenne, amit az adott tanulóközösségre szabott szabad oktatási tevékenység jelent. Fontos lenne tehát, hogy az egyéb központi ösztönzők növeljék a pedagógusok szakmai elhivatottságát, motivációját, ezzel együtt a jobb képességű diákok kedvét a pedagógusképzések választására. 


\section{Köszönetnyilvánítás}

A szerző köszönetet mond a (z egykori MTA) Közgazdaság- és Regionális Tudományi Kutatóközpont Adatbankjának a kutatás lebonyolításához szükséges technikai feltételek biztosításáért, valamint köszönöm Varga Júliának, Veroszta Zsuzsannának, Horváth Ágostonnak és a KRTK KTI Oktatás- és munkapiac csoportjának, akik ötleteikkel, meglátásaikkal hozzájárultak a tanulmány elkészüléséhez.

\section{IRODALOM}

Becker, G. (1975) Human Capital. A Theoretical and Empirical Analysis, with Special Reference to Education. Chicago, University of Chicago Press.

Blackburn, M. \& Neumark, D. (1993) Omitted-Ability Bias and the Increase in the Return to Schooling. Journal of Labor Economics, Vol. 11. No. 3. pp. 521-44.

Fazekas K. (2017) Merre halad a kereslet? A nem kognitív készségek felértékelődése. In: Fazekas K. \& KöLlő J. (eds) Munkaeröpiaci tükör 2016. Budapest, MTA KRTK KTI. pp. 150-159.

Griliches, Z. (1977) Estimating the Returns to Schooling: Some Econometric Problems. Econometrica, Vol. 45. No. 1. pp. 1-22.

Gunderson, M. \& Oreopoulos, P. (2010) Returns to Education in Developed Countries. In: D. J. Brewer \& P. J. McEwan (eds) Economics of Education. Oxford, Elsevier - Academic Press. pp. 37-43.

Hanushex, E. A. (2009) The Economic Value of Education and Cognitive Skills. In: G. Sykes, B. Schneider \& D. N. Plank (eds) Handbook of Education Policy Research. New York, Routledge. pp. 39-56.

Hermann Z., Horn D., Köllő J., Sebők A., Semjén A. \& Varga J. (2019) Szövegértési és matematikai kompetencia hatása a keresetre és foglalkoztatási esélyekre. In: Fazekas K., Csillag M., Hermann Z. \& Scharle Ä. (eds) Munkaeröpiaci tükör 2018. MTA KRTK, Budapest. pp. 45-52.

Kelly, E., O’Connell, P. \& Smyth, E. (2008) The Economic Returns to Field of Study and Competencies among Higher Education Graduates in Ireland. Economics of Education Review, Vol. 29. No. 4. pp. 650-657. https://doi.org/10.1016/ j.econedurev.2009.11.001.

Lazear, E. P. (2003) Teacher Incentives. Swedish Economic Policy Review, Vol. 10. No. 2. pp. 179-214.

Lindevist, E. \& Vestman, R. (2011) The Labor Market Returns to Cognitive and Noncognitive Ability: Evidence from the Swedish Enlistment. American Economic Journal: Applied Economics, Vol. 3. No. 1. pp. 101-128.

Mincer, J. (1958) Investment in Human Capital and Personal Income Distribution. Journal of Political Economy, Vol. 66. No. 4. pp. 281-302.

Mincer, J. (1974) Schooling, Experience and Earnings. New York, Columbia University Press.

Murnane, R. J., Levy, J. B. \& Willet. F. (1995) The Growing Importance of Cognitive Skills in Wage Determination. Review of Economics and Statistics, Vol. 77. No. 2. pp. 251-266. 
Ritchie, A. J., Bates, T. C. \& Deary, I. J. (2015) Is Education Associated with Improvements in General Cognitive Ability, or in Specific Skills?. Developmental Psychology, Vol. 51. No. 5. pp. 573-582.

Sево̋к A. (2019) A KRTK Adatbank Kapcsolt Államigazgatási Paneladatbázisa. Közgazdasági Szemle, Vol. 66. No. 11. pp. 1230-1236.

Schultz, T. W. (1960) Capital Formation by Education. The Journal of Political Economy, Vol. 68. No. 6. pp. 571-583.

Tyler, J. H., Murnane, R. J. \& Willett, J. B. (2000) Do the Cognitive Skills of School Dropouts Matter in the Labor Market? Journal of Human Resources, Vol. 35. No. 4. pp. 748-754.

VARGA J. (2013) A pályakezdő diplomások munkaerő-piaci sikeressége 2011-ben. In: Garai O. \& Veroszta Zs. (eds) Frissdiplomások 2011. Budapest, Educatio Társadalmi Szolgáltató Nonprofit Kft. 143-171.

VARGA J. (2019a, ed.) A közoktatás indikátorrendszere 2019. Közgazdaság- és Regionális Tudományi Kutatóközpont Közgazdaság-tudományi Intézet, Budapest.

VARGA J. (2019b) A fiatal diplomások munkaerőpiaci helyzete, túlképzettség, a diplomák értéke. In: Fazekas K., Csillag M., Hermann Z. \& Scharle Á. (eds) Munkaeröpiaci tükör 2018. Budapest, KRTK. pp. 134-140.

A cikk a Creative Commons Attribution 4.0 International License (https://creativecommons.org/licenses/ by/4.0/) feltételei szerint publikált Open Access közlemény, melynek szellemében a cikk bármilyen médiumban szabadon felhasználható, megosztható és újraközölhető, feltéve, hogy az eredeti szerző és a közlés helye, illetve a CC License linkje és az esetlegesen végrehajtott módosítások feltüntetésre kerülnek. (SID_1) 